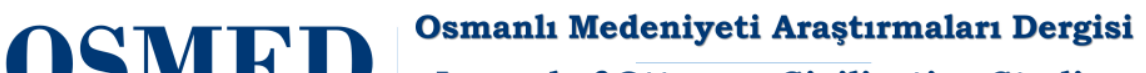 Journal of Ottoman Civilization Studies

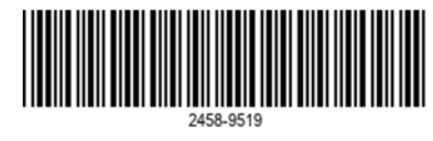

\section{İkinci Meşrutiyet Dönemi'nde Soru Önergesinin İşleyişi ve Uygulamasında Karşılaşılan Sorunlar}

Problems Encountered in the Functioning and Implementation of the Questionnaire in the Second Constitutional Period

\author{
Ahmet Ali Gazel \\ Prof. Dr. \\ Afyon Kocatepe Üniversitesi \\ Sosyal Bilgiler Eğitimi \\ agazel@aku.edu.tr
}

ORCID ID : 0000-0002-7211-6032

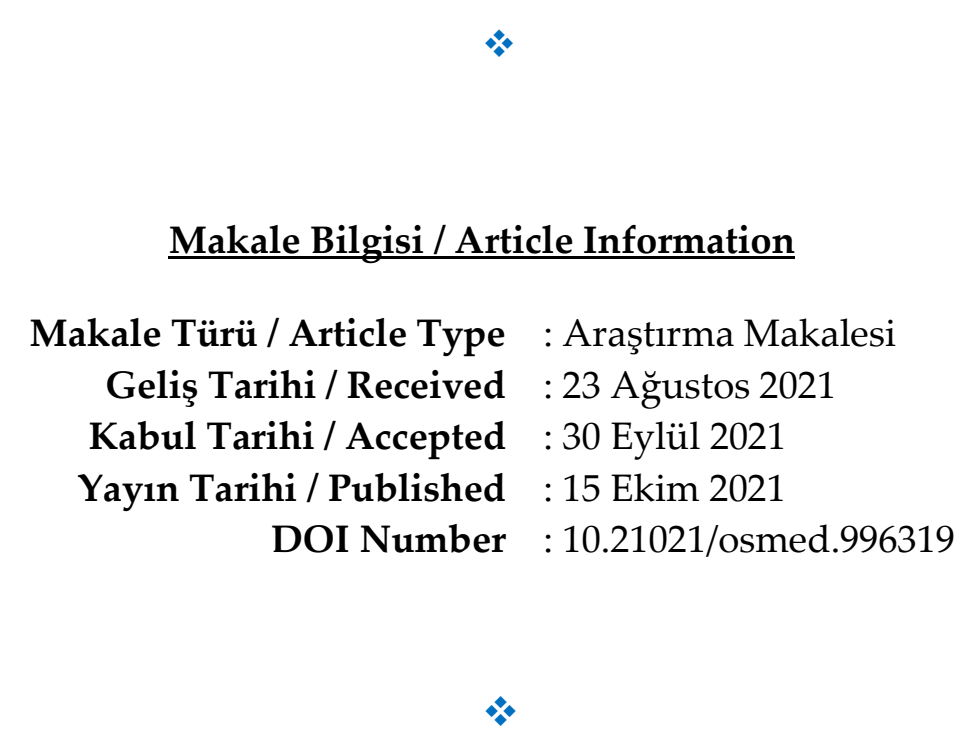

\section{Kaynak Gösterme / Citation}

Gazel, A. A. “İkinci Meşrutiyet Dönemi’nde Soru Önergesinin İşleyişi ve Uygulamasında Karşılaşılan Sorunlar". Osmanlı Medeniyeti Araştırmaları Dergisi, 13 (2021): 129-142. 


\title{
İkinci Meşrutiyet Dönemi’nde Soru Önergesinin İşleyişi ve Uygulamasında Karşılaşılan Sorunlar
}

\author{
Problems Encountered in the Functioning and Implementation of the Questionnaire in the Second \\ Constitutional Period
}

\section{Ahmed Ali Gazel}

\section{$\ddot{O z}$}

Kanun-ı Esasi'nin tam olarak parlamenter sisteme göre yapılandırılmamıs olmasından dolayı, I. Meşrutiyet Dönemi'nde parlamenter sistem pek çok yönden eksik kalmıştır. 1909 yılında KânunI Esasi'de yapılan değişikliklerle, parlamenter sistem oldukça demokratik bir yapıya kavuşturulmuştur. Ancak bazı hukuki eksiklikler ve tecrübesizlikler nedeniyle denetim mekanizmalarının işleyiş ve uygulamasında sorunlar yaşanmıştır. Örneğin ne Kanun-ı Esasi'de ne de 1877 Mebusan ve Ayan Meclisleri içtüzüklerinde, soru önergesine ait bir kural bulunmamaktadır. Bu nedenle II. Meşrutiyet Dönemi'nde soru önergeleri çeşitli tartışmalara neden olmuş ve bu dönemde soru önergeleri zamanla oluşan teamüllere göre işlemiştir.

Makalede, II. Meşrutiyet Dönemi'nde soru önergesinin işleyişi ve uygulamasında karşılaşılan sorunlar özellikle Meclis-i Mebusan Zabıt Ceridesi'ne dayalı olarak anlatılmıştır. Bunun yanında dönemin basınından ve araştırma eserlerden de yararlanılmıştır.

Anahtar Kelimeler: Osmanlı Devleti, Parlamenter Denetim, II. Meşrutiyet, Soru Önergesi

\section{Abstract}

Since the Constitution was not fully structured according to the parliamentary system, the parliamentary system was lacking in many ways during the First Constitutional Era. However, with the amendments made to the constitution in 1909, the parliamentary system was transformed into a very democratic structure. However, due to some legal deficiencies and inexperience, there have been problems with the operation and implementation of the control mechanisms. For example, neither in the constitution nor in the parliamentary regulations, there is no rule of question proposal. Therefore, in the Second Constitutional Era, the question motions caused various discussions and in this period the question motions were processed according to the practices.

In the article, the problems encountered in the functioning and implementation of the parliamentary question in the Second Constitutional Period are explained especially based on the Memorandum of the Parliament. In addition, the press and research works of the period will also be used.

Keywords: Parliamentary Auditing, Second Constitutional Monarchy, question proposal 


\section{Giriş}

Parlamenter yönetim, yasama ile yürütme ilişkilerine uyum ve denge getirme temeline dayanan bir sistemdir. Bu sistemin üç ana unsuru vardır: Birincisi, bir veya iki meclisten oluşan seçilmiş bir parlamento, ikincisi kral veya başkan statüsünü de haiz bulanabilecek sorumsuz bir devlet başkanı, üçüncüsü ise devlet başkanı tarafından meydana getirilen ve siyasî bakımdan parlamentoya karşı sorumlu olan kabinedir.

Kabinenin parlamento üzerindeki yetkileri; meclisi toplantıya çağırmak, gerektiğinde meclisi feshederek yeni seçimlere gitmek, kanun teklifinde bulunmak ve güvenoyu istemek şeklinde özetlenebilir. Buna karşın parlamentonun da kabine üzerinde murakabe hakk1 ve görevi vardır. Bu murakabe ve kontrolün yaptırımı ise kabinenin veya bakanların parlamento önündeki sorumluluğudur. Kabinenin veya münferiden üyelerinin maruz kalabilecekleri mesuliyet siyasî, cezaî veya malî olabilir. Parlamento önündeki mesuliyetleri ise parlamenter rejimin alâmet-i fârikası olarak görülen siyasî mesuliyettir. Siyasî mesuliyet müşterek olabilir, ancak malî ve cezaî mesuliyet şahsîdir. Malî ve cezaî mesuliyetin oluşabilmesi için kanunların ihlal edilmiş olması gerekmektedir. Ancak siyasî mesuliyet bu kadar somut ve açık değildir. Siyasî mesuliyet bir suç veya kusur olmaktan ziyade parlamento ile kabinenin tamamı veya bir kısım üyeleri arasındaki görüş farkı mahiyetindedir. Siyasî mesuliyetin neticesi ise istifa veya iktidardan düşürülme şeklinde sonuçlanır. Bunu sağlayan mekanizma da güvensizlik oyudur. Siyasî mesuliyet, ancak görevde olan kabine veya kabine üyeleri için geçerlidir. Cezaî ve malî sorumluluk ise hem hâlen görevde bulunanlara, hem de ayrılmış olanlara teşmil edilebilmektedir.

Parlamentoların kabineleri denetleme ve kontrol vasıtaları; soru, gensoru, meclis araştırması, meclis soruşturması ve genel görüşmedir. Bunlar arasında soru önergeleri dolaylı etki eden bir murakabe vasıtasıdır. Daha çok kamuoyunun dikkatini belli bir noktaya çekerek, kabineyi veya kabinenin bir üyesini parlamentonun ve kamuoyunun tenkit nazarı altına sokmaya matuftur. Netice itibariyle sadece bir parlamento üyesinin, kabineden veya kabinenin bir üyesinden bilgi istemesinden ibaret olan bir denetim vasıtasıdır. Gensoru ve meclis araştırması ise soru önergesinin aksine, neticeleri itibariyle hükûmeti veya üyelerini doğrudan etkileyebilen denetim vasıtalarıdır. Zira bunların sonucunda verilebilecek bir güvensizlik oyu ile kabine veya bazı üyeleri görevden düşebilmektedir. Meclis soruşturması yoluyla da ilgili bakanın veya başbakanın Yüce Divan'a gönderilmesi mümkündür. Parlamentoların kabineleri denetleme vasıtaları arasında en çok kullanılanı ise kısa sürede sonuç alınabilmesi, konu kapsamanın genişliği ve -genellikle- tek bir imza ile verilebilmesinden dolayı sorudur.

\section{Soru Önergesi}

Parlamentonun denetim araçlarından biri olan soru, kısaca bir veya daha fazla milletvekilinin bir konu hakkında hükûmetten bilgi istemesidir. Soru, istenilen cevabın niteliğine göre sözlü ve yazılı olmak üzere ikiye ayrılır. Sözlü soru, yazılı olarak verilen, fakat cevabın sözlü olarak istendiği sorulardır. Sözlü soru, ancak görevde olan başbakana veya bakanlara yöneltilebilir.

Hükûmetin umumî siyasetinden, idarî faaliyetlerinin en ince ayrıntılarına kadar her çeşit mesele sorunun konusu olabilir. Ancak bazı ülkelerde soru önergesinin konusunun sınırlandırıldı̆̆ da görülmektedir.

Soru önergelerinin şeklî şartlarına gelince; hemen hemen bütün parlamenter ülkelerde soru önergelerinin yazılı olarak verilmesi kabul edilmiş̧tir. Genellikle çoğu ülkede soru sorma milletvekillerinin şahsî bir denetimi olarak görüldüğü için soru önergelerinin bir milletvekili tarafından verilebileceği kabul olunmuştur. Sorunun esas gayesi bilgi almaktan ibaret olduğu için, soru sahibi önergede şahsî fikirlerini 
beyan edemez, iddialar serdedemez ve cevabı kendi içinde olamaz. Birçok ülkede ise sorunun kısa ve açık olması şart koşulmuştur.

Parlamento üyelerinin soru sorma hakkı hakkında genelde bir sınırlama yoktur. Ancak bazı ülkelerde bu hak sınırlandırılmıştır. Örneğin Almanya'da Bundestag üyesi bir parlamenterin her ay dört soru hakkı bulunmaktadir.

Soru önergeleri daima Meclis Başkanlığına verilir. Genellikle Meclis Başkanlarına, usule aykırı gördükleri soru önergelerini reddetme yetkisi verilmiştir. Soru önergeleri Meclis Başkanlığı tarafindan bir tezkere ile hükûmete veya ilgili bakana bildirilir. Soru gönderildikten sonra, cevap hazırlanması için ilgili hükûmet üyesine belirli bir müddet verilir. Ancak bu süre birçok ülkede kısa tutulmuştur. Birçok ülkede sözlü soruların cevaplandırılması için, haftanın belirli bir günü veya saati ayrılmıştır.

Soru önergesinin görüşülmesi bakımından üç sistem bulunmaktadır. Bunlardan birincisinde sözlü soru görüşmesi, soru sahibinin önergesini izah ettiği bir konuşmayla başlar. İkinci sistemde, soru metni, ya soru sahibi tarafından ya da Meclis Başkanı tarafından okunur ve arkasından soru sahibine ayrıca bir izah konuşması hakk1 verilir. Üçüncü sistemde ise, sorunun metni dahi okunmayarak gündemdeki yerinin belirtilmesi ile yetinilir.

Soruya muhatap olan bakanın veya başbakanın cevabı kısa, kaçamaklı olduğu veya tatminkâr görülmediği takdirde, bu müessese dairesinde yapılacak bir şey yoktur. Ancak soru sahibine tamamlayıcı soru sorabilme hakkı verilmesi, bu mahzuru bir derece hafifletmektedir. İçtüzüklerde cevabın, soru ile ilgili hususlara hasredilmesi mecburiyeti olmasına rağmen, pratikte bakanların belirli bir hareket serbestliğine sahip oldukları görülmektedir. Bazı ülkelerde cevap süresi sınırlandırılmıştır. Ayrıca bazı ülkelerde bakanların cevaptan kaçınma hakkı da bulunmaktadır.

Bakan cevabı öne alabildiği gibi, umumî menfaatler mülahazasıyla sorulara gizli oturumda da cevap verebilir. Soruya muhatap olan bakan veya başbakanın bizzat kendisi cevap vermek zorunda değildir ve temsilcileri vasıtasıyla sorulara cevap verebilirler. Yine bakanlar aynı konudaki soruları birleştirerek cevap verebilirler. Ancak bakanın cevabından sonra her iki önerge sahibi de konuşma hakkına sahiptir. Bakanın cevabından sonra soru sahibi tekrar söz alabilir. Bazı ülkelerde soru sahibinin konuşması yerine, soru sahibine ve diğer mebuslara tamamlayıcı soru sorma yetkisi verilmiştir.

Yazılı sorunun sözlü sorudan tek farkı, cevabın yazılı olarak verilmesidir. Yazılı sorular sözlü soru sayısını azaltarak meclise zaman kazandırmaktadır. Ayrıca alenî müzakere yapılması sakıncalı olan bazı durumlarda da meclisin denetimini kolaylaştırmaktadır.

\section{Türk Parlamento Hukuku'nda Soru Önergesi}

1876 yılında ilan edilen Kanun-1 Esasi'de ve 1877 y1lında hazırlanan Ayan ve Mebusan Dahilî Nizamnâmelerinde (İçtüzüklerinde) soru önergesine (sual takriri) ait bir kural bulunmamaktadır. Dolayısıyla I. Meşrutiyet Dönemi'nde soru önergelerine ait hukukî bir kayıt yoktur. II. Meşrutiyet Dönemi'nde de soru önergesiyle ilgili olarak Kanun-1 Esasi'ye bir madde eklenmemiştir. Soru önergesi ilk olarak, 12 Aralık 1918 tarihinde Meclis gündemine gelen içtüzük taslağında yer almıştır. Ancak II. Meşrutiyet Dönemi'nde soru ile ilgili maddelerin görüşülmesi bitirilemeden Meclis-i Mebusan feshedilmiştir.

TBMM, 26 Nisan 1920 tarihinde Mebusan Meclisi'nin 13 Mayıs 1877 tarihli değiştirilmiş içtüzüğünde bazı değişiklikler yapılarak uygulanmasını kabul etmiştir. Hangi maddelerin değiştirileceğini belirlemek 
için bir komisyon kurulmuştur. Bununla birlikte, and içme, komisyonlar, toplantı yılı başlangıcı ve dilekçeler konuları dışında herhangi bir somut adım atılamamıştır. 11 Kasım 1924 tarihinde yeni bir içtüzük komisyonu kurulmasına karar verilmiştir. Komisyonun hazırladığı içtüzük taslağı 2 Mayıs 1927 tarihinde kabul edilerek yürürlüğe girmiştir.

2 Mayıs 1927 tarihindeki içtüzük değişiklerine kadar soru ile ilgili olarak da genelde, II. Meşrutiyet Dönemi'ndeki teamüllere göre hareket edilmiştir. Yalnız, 6 Aralık 1923 tarihindeki 63. oturumda, içtüzüğün soru ile ilgili 111. maddesinin son fikrasında bir değişiklik yapılmıştır. Buna göre soru sahibi, sorunun cevaplanacağı gün Meclis'te hazır bulunmazsa sorunun bir defaya mahsus olmak üzere ertesi toplantıya ertelenmesi kabul edilmiştir. Ayrıca soru sahibinin isterse başka bir önergeyle sorusunu tekrar edebileceği de kabul edilmiştir.

Soru, bir anayasa kuralı olarak, ilk defa 1924 Anayasası'nda yer almıştır: "Sual, istizah ve meclis tahkikatı Meclis'in cümle-i salahiyetinden olup şekl-i tatbiki Nizamnâme-i Dahilî ile tayin olunur" (Madde 22). 1927 y1lında kabul edilen içtüzüğün de 149-156 maddeleri soru önergesi ile ilgilidir. Bu içtüzüğe göre soru önergesi, "sarih ve muayyen maddeler hakkında malumat istemekten ibarettir" (Madde 150).

Soru önergelerinin işleyişi konusunda 1957 yılına kadar, 2 Mayıs 1927 tarihinde kabul edilen içtüzük geçerli olmuştur. Ancak 28 Aralık 1957 tarihinde, 1927 yılında kabul edilen içtüzüğün 27 maddesi değiştirilmiştir. Bunlar arasında soruyla ilgili maddeler de bulunmaktadır.

Demokrasinin 27 Mayıs 1960 Askeri Darbesiyle kesintiye uğraması neticesi TBMM feshedilmiş ve TBMM İçtüzüğü de askıya alınmıştır. 13 Aralık 1960 tarih ve 157 sayılı yasa ile yasama görevini Millî Birlik Komitesi, Temsilciler Meclisi ve bunların ikisinin oluşturduğu Kurucu Meclis üstlenmiş ve bu tarihten yeni anayasanın ilan edildiği 1961 yılına kadar Millî Birlik Komitesi, Temsilciler Meclisi ve bunların ikisinin oluşturduğu Kurucu Meclis'in içtüzükleri geçerli olmuştur. 9 Temmuz 1961 tarihinde 1961 Anayasası'nın yürürlüğe girmesiyle bu içtüzüklerin geçerliliği kalkmıştır. 1961 Anayasası'na konan geçici 3. maddede TBMM'nin, Millet Meclisi'nin ve Cumhuriyet Senatosu'nun içtüzükleri yapılıncaya kadar, 1957 yılından önce yürürlükte olan içtüzüğü kullanacağı kaydedilmiştir. Yine geçici 7/2 maddeye göre; TBMM, Cumhuriyet Senatosu ve Millet Meclisi'nin en fazla iki yıl içerisinde kendi içtüzüklerini yapmaları gerekmekteydi. Cumhuriyet Senatosu İçtüzüğü 27 Aralık 1963 yılında, TBMM İçtüzüğü 17 Aralık 1965 tarihinde kabul edilebilmiştir. Millet Meclisi için hazırlanan tasarı ise uzun müddet müzakereye konamamıştır. Millet Meclisi kendi içtüzüğünü, ancak 5 Mart 1973 tarihinde kabul edebilmiştir. Bu tarihe kadar Millet Meclisi, 1927 yılında kabul edilen içtüzügü kullanmıştır.

1961 Anayasası'nda soru önergesinin her iki meclisin yetkisinde olduğu yazılıdır (Madde 88). Cumhuriyet Senatosu İçtüzüğü'nün 117-125. maddeleri de soru ile ilgilidir.

Millet Meclisi İçtüzüğü 5 Mart 1973 tarihinde kabul edilmiş ve 1 Eylül 1973 tarihinde yürürlüğe girmiştir. Dolayısıyla 1 Eylül 1973 tarihine kadar, çeşitli değişikliklerle beraber, 1927 yılında kabul edilen içtüzük geçerli olmuştur. 1973 yılında yürürlüğe giren Millet Meclisi İçtüzüğü’ne göre soru, "kısa, gerekçesiz ve şahsî görüş ileri sürülmeksizin bir önerge ile hükûmet adına sözlü veya yazılı olarak cevaplandırılmak üzere, başbakan veya bir bakandan açık ve belli konular hakkında bilgi istemekten ibarettir".

12 Eylül 1980 darbesinden sonra Millî Güvenlik Konseyi (MGK), TBMM’yi feshetmiş ve yasama yetkisini kendisi üstlenmiştir. MGK, yasama görevini yerine getirebilmek için 25 Eylül 1980 tarihinde MGK Yasama Görevleri İçtüzügü’nü yürürlüğe koymuştur. 23 Ekim 1981 tarihinde de, MGK ile yasama 
işini beraber yürütmek üzere Danışma Meclisi kurulmuştur. Danışma Meclisi de, kendi içtüzüğünü hazırlayıncaya kadar MGK İçtüzügü ile çalışmıştır. Danışma Meclisi kendi içtüzügünü ise 20 Kasım 1981 tarihinde kabul etmiştir.

Danışma Meclisi'nin hazırladığı Anayasa, 7 Kasım 1982 tarihinde halkoyu ile kabul edilmiştir. 1982 Anayasası'nın 98. Maddesine göre soru, "Bakanlar Kurulu adına, sözlü ya da yazılı olarak cevaplandırılmak üzere Başbakan veya bakanlardan bilgi istemekten ibarettir".

1982 Anayasası, 1961 Anayasası'nın aksine tek meclisli sistem getirmiştir. 1982 Anayasası'nın geçici 6. maddesine göre ise, yeni içtüzük yapılıncaya kadar TBMM'nin 12 Eylül 1980 tarihinden önce yürürlükte olan içtüzügün Anayasaya aykırı olmayan hükümlerini uygulaması kabul edilmiştir. TBMM’ye içtüzük yapması için belirli bir süre verilmemiştir. Ancak bu süre çok uzun sürmüştür. TBMM ise yeni bir içtüzük yapmaktansa eski içtüzüğün bazı maddelerini değiştirerek aynen kullanmıştır. 8 Mayıs 1996 tarihinde başlayan içtüzük değişikliği 16 Mayıs 1996 tarihinde bitmiş ve içtüzüğün 29 maddesi değiştirilmiştir. 1996 yılında yapılan değişikliğe göre, soru "kısa, gerekçesiz ve şahsî görüş ileri sürülmeksizin kişilik ve özel yaşama ilişkin konuları içermeyen bir önerge ile hükûmet adına sözlü veya yazılı olarak cevaplandırılmak üzere, başbakan veya bir bakandan açık ve belli konular hakkında bilgi istemekten ibarettir”.

2017 yılında yapılan referandum sonucu anayasada yapılan değiş̧iklikle Türkiye'de Cumhurbaşkanlığı Hükümet Sistemi'ne geçilmiştir. Bu hükümet sistemi değişikliği neticesi olarak 1982 Anayasası'ndan sözlü soru kaldırılmış ve milletvekillerine sadece yazılı soru sorma hakkı tanınmıştır. 1982 Anayasası'nın 2017 yılında değiştirilen 98. maddesine göre yazılı soru "yazılı olarak en geç on beş gün içinde cevaplanmak üzere milletvekillerinin, Cumhurbaşkanı yardımcıları ve bakanlara yazılı olarak soru sormalarından ibarettir”. TBMM İçtüzüğü de 2017'de yapılan anayasa değişikliğine göre 2018 yılında yeniden düzenlenmiş̧tir. İçtüzüğün değiştirilen 96. maddesine göre yazılı soru "kısa, gerekçesiz ve kişisel görüş ileri sürülmeksizin; kişilik ve özel yaşama ilişkin konuları içermeyen bir önerge ile yazılı olarak cevaplanmak üzere milletvekillerinin, Cumhurbaşkanı yardımcıları ve bakanlara yazılı olarak soru sormalarından ibarettir'. İçüzüğün 99. maddesi yazılı sorunun cevabı ve 100. maddesi ise Başkanlıktan sorular ile ilgilidir. TBMM'de hâlen bu içtüzük kuralları geçerlidir.

\section{II. Meşrutiyet Dönemi’nde Soru Önergesinin İşleyişi ve Karşılaşılan Sorunlar}

Kanun-1 Esasi'de ve 1877'de hazırlanan Ayan ve Mebusan İçtüzüklerinde soru önergesine ait bir kural bulunmamaktadır. Dolayısıyla I. Meşrutiyet Dönemi'nde soru önergelerine ait hukukî bir kayıt yoktur. II. Meşrutiyet Dönemi'nde de soru önergesiyle ilgili olarak Kanun-1 Esasi’ye bir madde eklenmemiştir.

Soru önergesi ilk olarak, 1915 yılında bir komisyon tarafından hazırlanıp 12 Aralık 1918'de Meclis gündemine gelen içtüzük taslağında yer almıştır. İçtüzük taslağının soru ile ilgili maddeleri şöyledir:

107- Her mebus vükelâ-yı devletten birine şifahî veya tahrirî sualler irad edebilir.

108- Sual: Falan vak'a doğru mudur, falan haber hükûmetçe mesmu olmuş mudur veya sahih midir, hükûmet falan mesele hakkında bir karar vermiş midir veya vermek üzere midir? Tarzında kısa ve sarih malumat talebinden ibarettir. Sual varakasında cevabının şifahî (yani heyet-i umumiye muvacehesinde) veya tahrirî (yani ceride-i müzakerat nihayetine derc edilmek suretinde) olduğu tasrih edilmek muktazidir. Sual varakasını yalnız bir mebus imza edebilir.

109- Vükelâdan birine tahrirî sual irad etmek isteyen bir mebus bunun metnini Reise takdim eder. Riyaset bu suali derhal nazır-1 aidine tebliğ eyler ve nihayet üç gün zarfında fezleke-i müzakeratın sonuna 
aynen dercettirir. Nazır cevabını tahriren Riyasete ita eder. Bu cevap, sualin tarih-i tevdiinden on gün zarfında sual ile birlikte ceride-i müzakeratın nihayetinde neşrolunur.

110- Şifahî sualler metni, tahriren Riyasete tevdi olunur. Riyaset bunları nazır-1 aidine tebliğ ile beraber fezleke-i müzakeratın nihayetine dercettirir ve ertesi celsenin ruznamesine tevdi sırasıyla idhal eyler.

111- Celse ibtidasında Riyaset ruznamede dahil olan sualleri kıraat ettirir, sualin taalluk ettiği nazır cevap verir. Nazırlar gerek tahrirî, gerek şifahî suallere menafi-i umumiye mülahazasına mebnî cevap veremeyeceklerini yahut malumat-1 muktaziyenin istihsali maksadıyla cevaplarını bir müddet tehir edeceklerini beyan edebilirler. Sahib-i sual olan bir mebus sorusunun esna-yı kıraatinde hazır bulunmazsa sualini geri almış addolunur.

112- Nazır-1 mesulün cevabını müteakip yalnız sual irad eden mebus beyan-1 mütalaa hakkını haizdir. Ancak mütalaa-i vakıa beş dakikadan ziyade imtidad edemez.

113- Celsenin küşadından itibaren yarım saat mürurunda ruznamede dahil bulunan sualler nihayet bulmamışsa, Riyaset mütebakisini ertesi ruznameye diğerlerini tercihan ithal ederek ruzname-i müzakerata geçer.

114- Hükûmet bu sualin müstaceliyetine hükmettiği takdirde, istediği zamanda diğerlerine takdimen buna cevap verebilir.

115- Bütçe müzakeresi esnasında mebuslar, nezaretinin bütçesi der-dest-i tezekkür olan nazıra, sualler hakkındaki kuyuda tâbi olmaksızın her faslın müzakeresinde o fasıla ait istedikleri sualleri irad edebilirler.

116- Sual neticesinde reye müracaat olunmaz.

Soru önergesi ile ilgili maddelerin görüşülmesi bitirilemeden 21 Aralık 1918 tarihinde Meclis-i Mebusan feshedildiği için belirtilen maddeler II. Meşrutiyet Döneminde bir içtüzük kuralı olamamıştır.

Yukarıda belirtildiği gibi mevzuatta olmamasından dolayı II. Meşrutiyet Dönemi'nde soru önergesi devamlı tartışma konusu olmuştur. Ancak bu tartışmalar ve hukukî yoksunluk, mebusların soru müessesesini kullanmalarına engel teşkil etmemiştir. II. Meşrutiyet Dönemi Meclis Başkanlarından Menteşe Mebusu Halil (Menteşe) Bey soru önergesi hakkındaki hukukî boşluğu şöyle dile getirmiştir:

“Kanun-1 Esasi'de 'istizah önergeleri ekseriyetin kararıla kabul olunur' diye sarahat vardır ve öteden beri bu sarahat dâhilinde ifa-yı muamele edilmiştir. Fakat sual takrirlerini Heyet-i Celileniz isterse istizah, isterse sual şeklinde kabul eder. Fakat istizahta bir mecburiyet-i kanuniye var. Çünkü o ekseriyetle kabul olunur. Fakat sual takrirleri için esasen Kanun-1 Esasimizde bir madde olmadığ gibi Nizamnâmemizde de sual takrirlerinin ekseriyetle kabulüne dair bir sarahat yoktur ve binaenaleyh bunun vech-i tatbiki de bu suretle cereyan eylemektedir. Mamafih Heyet-i Celileniz nasıl arzu ederse o suretle olur”.

Serfiçe Mebusu Yorgi Boşo Efendi de 21 Temmuz 1909'da soru önergesi hakkında Kanun-1 Esasi'de bir madde bulunmadığı gerekçesiyle, Gümülcine Mebusu İsmail Bey'in Adana' da tutuklanan İtidal gazetesi sahibi İhsan Beyle ilgili verdiği soru önergesinin kabul edilmemesini istemiştir. Aydın Mebusu İsmail Sitkı Bey, 15 Şubat 1910'da Kanun-1 Esasi'ye göre nazırların ancak gensoru suretiyle Meclis'e davet edilebileceklerini ve soruya cevap vermek için nazırları Meclis'e getirmeye haklarının olmadığını savunmuştur. 
Kanun-1 Esasi değişikleri görüşülürken 9 Haziran 1909 tarihinde Bağdat Mebusu İsmail Hakkı Bey bir önerge vererek, soru önergesinin Kanun-1 Esasi’ye eklenmesini teklif etmiştir. Meclis Başkanı, bu önergenin içtüzük ile ilgili olduğunu belirterek işleme koymamıştır. Ancak Bağdat Mebusu İsmail Hakkı Bey söz alarak önergesini savunmuştur. Kanun-1 Esasi'de sadece güven oylaması ile sonuçlanan gensoru olduğunu, bu nedenle de en basit meselelerde bile oylama yapıldığını söylemiştir. İsmail Hakkı Bey, hükümeti düşürmemek için Meclis'in birçok meseleyi soramadığını veya doyurucu bilgi alamasa bile, müzakereyi yeterli görmek zorunda kaldığını söyleyerek teklifinin kabul edilmesini istemiştir. Karahisar-1 Şarkî Mebusu Mustafa Efendi de her meselenin gensoru şekline konarak Meclis’in bir hayli yorulduğunu, önemsiz birçok konuda uzun müzakereler yapılarak zaman kaybı olduğunu savunmuş ve önerge içeriğinin Kanun-1 Esasi'ye eklenmesini istemiştir. İstanbul Mebusu Ahmet Nesimi Bey ise bu işin içtüzük meselesi olduğunu ve Kanun-1 Esasi'ye eklenemeyeceğini, ayrıca gensoru hakkının soru hakkını da ihtiva ettiğini savunmuştur. Meclis Başkanı, İsmail Hakkı Bey’in önergesini oya sunmuş, ancak soru önergesinin Kanun1 Esasi'ye girmesi teklifi kabul edilmemiştir.

Soru önergesinin Kanun-1 Esasi'ye eklenmesinin reddedilmesinden sonra, Kütahya Mebusu Ahmet Ferit Bey, 28 Aralık 1910 tarihinde diğer parlamentolardaki soru kurallarına uyulmasını teklif etmiştir. Buna göre, soru soracak mebusun önceden giderek nazırla görüşmesi ve nazırın onayını aldıktan sonra soru önergesi vermesi gerekmekteydi. Ancak Ahmet Ferit Bey’in bu teklifi de kabul edilmemiştir.

II. Meşrutiyet Dönemi'nin ilk günlerinde hukukî yetersizlikten dolayı kanunların soruya müsaade etmediğini düşünen mebuslar, soru ile sorulabilecek meseleleri de gensoru ile sormuşlardır. Gensoru önergesinin Meclis'in kabulüne bağlı olması ise bir hayli zamanın heba olmasına neden olmuştur.

Soru önergeleri, yukarıda da belirtildiği gibi, anayasa ve içtüzüklerde yer almamasından dolayı, II. Meşrutiyet Dönemi'nin büyük bir bölümünde birçok yönden gensoru kurallarına uygun şekilde işlemiştir. Soru önergesinin kabul edilmesi için meclis kararına gerek olmamasına rağmen, ilk yıllarda sorular da gensoru önergeleri gibi çoğunluğun kararı ile kabul edilmiştir. Yine ilgili nazırın cevabından sonra cevabın yeterli olup olmadığının oya sunulmasına gerek olmamasına rağmen, gensoru kaidesine uyulduğu için soru sonrası cevabın yeterliliği meclisin onayına sunulmuştur. Bir diğer durum da oya sunularak reddedilen soru önergelerinin olmasıdır. II. Meşrutiyet Dönemi’nde altı soru önergesi, aynı gensoru önergesi gibi oya sunulmuş ve reddedilmiştir.

II. Meşrutiyet Dönemi'nde soru önergelerinin işleyişine gelince; Soru önergeleri yazılı olarak Meclis Başkanlığı’na verilmiştir. Genelde soru önergelerini bir mebus vermiştir. Bunun yanında birden fazla imza ile verilen soru önergeleri de bulunmaktadır.

II. Meşrutiyet Döneminde soru önergesiyle sorulabilecek konular hakkında herhangi bir sınırlama bulunmamaktadır. Mebuslar her konuyu soru olarak sorabilmişlerdir.

Soru önergelerinin muhatabı hükûmetin başı olarak sadrazam, hükûmet veya nazırlardır. Bazı sorular iki nazıra birden sorulmuştur. II. Meşrutiyet'in sonlarına doğru ise soru önergeleri genelde hükûmetin cevaplandırması istemiyle verilmiştir. Açık, anlaşılır olmayan ve genel konuları içeren soru önergeleri kabul edilmemiştir.

Meclis Başkanı verilen soru önergelerinin, veriliş sırasına göre ya özetini ya da tam metnini okutmuştur. Ancak önergenin okunup okunmaması meselesi zaman zaman tartışma konusu olmuş ve mebuslar bu konuda rahatsızlıklarını dile getirmiştir. Örneğin Karesi Mebusu Hüseyin Kadri Bey’in, bazı askerî tayinlerle ilgili olarak 2 Aralık 1918'de hükûmetin cevaplandırması için verdiği gensoru önergesi 
görüşülürken, Sivas Mebusu Dikran Efendi soru önergelerinin okunmasında sakınca olup olmadığını sormuştur. Meclis Başkanı da teamüle göre soru önergelerinin önce hükûmete tebliğ edildiğini, hükûmetten gelecek cevaba göre okunduğunu ve cevap gelmeden önergeleri okumanın Meclis'in zamanını zayi etmek olacağını söylemiştir. Dikran Efendi ise vaktin zayi olacağı fikrine katılmadığını, aksine okunmasının yararlı olacağını savunmuştur. Bunun üzerine Meclis Başkanı, bütün parlamentolarda uygulanan usule göre önergenin önce hükûmete tebliğ edildiğini, hükûmetin soruya cevap vermeye geldiği gün de önergenin okunduğunu belirttikten sonra, hükûmete tebliğ edilmeden önce okunması istenirse bunda da bir sakınca olmadığını söylemiştir. Daha sonra söz alan Trabzon Mebusu Yorgi Yuvanidis Efendi ise Başkan ile Başkan vekillerinin soru önergesi usulü hakkında bir birlikteliklerinin olmadığından şikâyet etmiştir. Bunun üzerine Meclis Başkanı, Kanun-1 Esasi'de "istizah takrirleri ekseriyetin kararıla kabul olunur" dendiğini hatırlatarak gensoru önergelerinin mecburen okunmak zorunda olduğunu, ancak ne Kanun-1 Esasi'de ne de içtüzükte soru önergelerinin çoğunlukla kabul edilmesine dair bir açıklık olmadığını, bu nedenle çeşitli uygulamalar görüldügünü belirttikten sonra, bundan sonra heyet nasıl isterse öyle yapılabileceğini söylemiştir.

Soru önergesi okunduktan sonra ilk zamanlarda çoğunluğun kararıyla kabul edilmiştir. Ancak zaman ilerledikçe ve soru müessesesi yerine oturdukça, soru önergeleri Meclis’in kabulüne ihtiyaç duyulmadan ilgili makama gönderilmiştir. Örnek olarak, 30 Ekim 1911 tarihinde Aydın Mebusu İsmail Sitkı Bey'in soru önergesi okunduktan sonra Meclis Başkanının ne yapılması gerektiğini sorması üzerine Yozgat Mebusu Hayrullah Efendi, 'Bunda sorulacak bir şey yok' demiştir. Bunun üzerine Meclis Başkanı da, 'bu bir sual teklifi kabul edersiniz’ demiş ve soru önergesi kabul olunmuştur.

Soru önergesi okunduktan sonra görüşme açılmamış ve kimseye söz verilmemiştir. Ancak zaman zaman soru sahibinin önergesini açıklaması istenmiştir.

Soru önergesinin Meclis tarafından kabul edilmesinden sonra Başkanlık, önergeyi ait olduğu nezarete göndermiştir. Bununla birlikte Birinci Yasama Döneminin birkaç oturumunda nazır kabul etmeden, soru sorulamayacağı iddia edilmiştir. Aynı tartışma İkinci Yasama Dönemi'nin 1. Toplantı Yılı'nda da yaşanmıştır. İzmit Mebusu İsmail Canpolat söz alarak içtüzükte soru önergesinin olmadığını, ancak daha önce feshedilen Meclis'in teamülü gereğince soru önergesi verildiğini hatırlattıktan sonra, soru soracak mebusun önceden nazırla görüşerek onay alması gerektiğini savunmuştur. Ayrıca Birinci Yasama Dönemi'nde uygulanan soru usulünün Hukuk-1 Esasiye'ye de (Anayasa Hukuku) aykırı olduğunu iddia etmiştir. Meclis Başkanı ise Birinci Yasama Dönemi’nde mebusların teamül gereğince soru önergesi verdiklerini ve Meclis'te kabul edildikten sonra nazıra gönderildiğini, hâlbuki diğer memleketlerde usulün Canbolat Bey'in söylediği gibi olduğunu belirttikten sonra, soru önergesinde takip edilen usulün Canbolat Bey'in söylediği şekilde olmasını oya sunmak istemiştir. Dönemin muhalif mebuslardan Çamlık Mebusu Şahin Bey'in buna tepkisi "aman Reis Bey !" olmuştur. Teklife tepki gösteren bir mebus da Konya Mebusu Zeynelabidin Efendi olmuştur. Zeynelabidin Efendi, bu teklifin kabul edilmesinin soru hakkını sınırlandırmak olacağını, ayrıca değişikliğin böyle ani bir teklif ile oya sunulamayacağını söylemiştir. İstanbul Mebusu Hallaçyan Efendi, soru sorabilmenin her mebusun hakk1 olduğunu belirttikten sonra, nazırdan alınacak onayın sorunun esası için değil, sorunun cevaplanacağı günü tayin için olduğunu belirtmiştir. İsmail Canbolat Bey tekrar söz alarak, eski Meclis'in soru usulünü teamülen uyguladığını ve içtüzüğe kaydettirmediğini, dolayısıyla kendilerinin de bu teamüle uymak zorunda olmadıklarını belirttikten sonra, nazır eğer soruya onay vermezse mebusun sorusunu gensoruya dönüştürebileceğini söylemiştir. Bunun üzerine Çamlık Mebusu Şahin Bey, "ekalliyet bu hakkı nasıl istima edecek" diyerek tepki göstermiştir. İstanbul Mebusu Hallaçyan Efendi, gensoru önergelerinin Meclis'in kabulüne bağl1 
olduğunu hatırlattıktan sonra, sorunun da bu şekilde kayıt altına alınmamasını, aksi takdirde ekalliyetin soru hakkını kullanamayacağını belirtmiş, ancak sorunun cevaplanacağı günü belirlemede nazırın onayının alınmasının şart olduğunu söylemiştir. Tartışmaların uzaması üzerine Meclis Başkanı, eski teamülün devam ettiğini ve bu teamül gereğince de soruyu kabul edenlerin ellerini kaldırmasını istemiştir. Bunun üzerine birkaç mebus, soru önergesinin Meclis onayı olmadan kabul edilmesi gerektiğini söylemiştir. Meclis Başkanı ise teamüle göre şimdiye kadar bütün soru önergelerinin aynı gensoru gibi Meclis'in onayı alınarak nezaretlere gönderildiğini söylemiş ve tartışmayı bitirmiştir.

Soru önergelerinin cevaplanacağı gün Meclis tarafından belirlenmiştir. Ancak çoğunlukla sorunun muhatabı olan nazırla görüşülerek Başkanlık tarafından bir gün tayin edilmiştir. Kendisine soru sorulan nazır ya kendi gelmiş ya da bir vekilini göndererek konu hakkında cevap vermiştir. Hangi nazıra, hangi memurun vekillik edebileceği zaman zaman Meclis’te tartışmaya neden olmuştur. 30 Aralık 1916 tarihinde İçtüzüğün 188. maddesinde yapılan değişiklikle, hangi nazıra hangi memurun vekâlet edebileceği açıkça belirlenmiştir.

Nazır veya vekili cevap vermeden önce, bazen önerge sahibi sorusunu açıklıyor ve nazır ondan sonra cevap veriyordu. Nazır isterse, mecliste okunarak kabul edildiği günde de soruya cevap verebiliyordu. Nazırın cevabına ise sadece soru sahibi olan mebus karşılık verebiliyordu. Soru önergeleri sırasında bazen diğer mebuslar da nazıra karşı1ık vermek istemiş, ancak Meclis Başkanı buna izin vermemiştir. Ayrıca soru sahibi mebusun konuşmasından sonra nazırın tekrar söz aldığ 1 da olmuştur.

Nazırlar isterlerse mazeret göstererek açıklamalarını ertelemişlerdir. Soru önergesine sonradan yapılan eklemeler ise cevap sırasında dikkate alınmamıştır. Eğer önergeler aynı konuyu ihtiva ediyorsa birleştirilmiş ve ilgili nazırın iki soruya birlikte cevap vermesi istenmiştir.

II. Meşrutiyet Dönemi'nde soruların cevaplandırılması ile ilgili olarak bir süre öngörülmemiştir. Bu süre genelde Meclis Başkanlığı tarafindan belirlenmiş veya hükûmetin cevabı beklenmiştir. Ancak bu durum bazı soruların cevaplandırılmasının uzamasına neden olmuştur. Ayrıca soru önergesini cevaplayan nazırın ve soru sahibi mebusun konuşma sürelerine ait bir sınırlama da bulunmamaktadır.

II. Meşrutiyet Dönemi Meclis-i Mebusan İçtüzügü’nde gündem maddelerinin görüşülmesine ait bir sıra bulunmamaktadır. Bu nedenle soru önergesinin hangi sırada görüşüleceğine dair bir açıklık yoktur. Soru önergeleri farklı zamanlarda farklı sıralarda cevaplandırılmıştır. Örnek olarak, 8 Temmuz 1912 tarihinde 1912 Bütçesi görüşülürken, Süreyya Bey ve arkadaşlarının verdiği soru önergesini cevaplamak üzere Dâhiliye Nazırının Meclis'e gelmesi üzerine, bütçe görüşmeleri kesilmiş ve Nazırın soru önergesine cevabı dinlenilmiştir. Aynı durum diğer denetim araçları için de geçerlidir.

II. Meşrutiyet Dönemi'nde bir nazır, mevcut haricî durumun cevaba engel teşkil ettiğini ileri sürerek soruyu cevaplamaktan kaçınmıştır.

Nazırın veya vekilinin cevabından sonra Meclis Başkanı, açıklamanın yeterli olup olmadığını oya sunmuş ve cevabın yeterli görülmesiyle gündemin diğer maddelerine geçilmiştir. Ancak II. Meşrutiyet'in sonlarına doğru mebuslar, soru önergeleri sonunda cevabın yeterliliğinin oya sunulmasına itiraz etmişlerse de bu uygulama nispeten devam etmiştir. Soru önergesinin görüşmesinden sonra genelde cevap yeterli görülmüştür. Bazen de sorunun gensoruya çevrilmesi ile ilgili önergeler verilmiştir. Bunun için genelde iki önerge veriliyordu. Bu önergelerin birisinde sorunun gensoruya çevrilmesi, diğerinde de gensoruya gerek olmadığı teklif ediliyordu. 
Meclis Başkanı cevap yeterli görüldükten sonra kimseye söz hakkı vermemiştir. Ayrıca önergede birden fazla imza varsa ilk imza sahibi dışındakilere de söz hakkı tanınmamıştır.

Soru önergelerinde genelde, yazılı mı yoksa sözlü mü cevap istendiği belirtilmemiştir. Ancak 1918 yılındaki soru ile ilgili bazı maddelerin görüşülmesinden sonra, soru önergesinin yazılı mı yoksa sözlü mü olduğunun belirtilmesini isteyen mebuslar çıkmıştır. Örnek verilecek olursa; Trabzon Mebusu Ali Şükrü Bey, 16 Şubat 1920'de sansür hakkında Dâhiliye Nazırının cevaplandırması için bir soru önergesi vermiştir. Karesi Mebusu Abdülaziz Mecdi Efendi, içtüzükte sözlü ve yazılı olmak üzere iki kısım soru önergesi olduğunu hatırlattıktan sonra, bu önergenin hangisi olduğunun ifade edilmediğini, nazırın buna sözlü mü yoksa yazılı mı cevap vereceğinin önergede belirtilmesi gerektiğini söylemiştir. Meclis Başkanı, içtüzükteki soru maddelerinin tam olarak kabul edilmediğini belirterek, nazırın sözlü veya yazılı olarak cevap verebileceğini ifade etmiştir. Meclis Başkanı'nın bu sözünden de anlaşılacağı gibi, II. Meşrutiyet Dönemi'nde hukukî kayıt eksikliğinden dolayı yazılı ve sözlü sorunun cevaplanması hususunda bir keyfilik yaşanmıştır. Ayrıca soru önergesi ile ilgili kabul edilen dört içtüzük maddesinin daha sonraki uygulamalarda her zaman dikkate alınmadığı anlaşılmaktadır. II. Meşrutiyet Dönemi'nde verilen soru önergelerinden sadece iki tanesi yazılı sorudur.

Nazırın açıklamaları yeterli görülmezse, soru önergesi gensoruya dönüştürülmüştür. Soru önergesi cevaplandırıldıktan sonra sadece soru sahibi değil, her mebus soru konusunu gensoruya çevirmek için önerge verebilmiştir. II. Meşrutiyet Dönemi’nde beş soru önergesi, gensoruya çevrilmiştir.

Meclis, mebusların verdiği herhangi bir önergeyi de soru önergesi olarak kabul edebilmiştir. Örnek olarak, Karesi Mebusu Hüseyin Kadri Bey'in Mütareke şartlarına aykırı olarak yapılan askerî işgallerin bütün dünya meclisleri nezdinde protesto edilmesi konusunda Meclis Başkanlığı'nın yetkili kılınmasına dair önergesi, soru önergesi olarak kabul edilmiştir.

Mebuslar zaman zaman soru önergelerine hükûmetin cevap vermediğinden şikâyet etmişlerdir. Bazen de önergelerinin geç gündeme gelmesinden ve geç cevaplanmasından şikâyetçi olmuşlardır.

II. Meşrutiyet Dönemi'nde karşılaşılan problemlerden biri de soru önergelerindeki şeklî eksikler olmuştur. Mebusların kullandığı ifadeden önergenin gensoru mu yoksa soru mu olduğu anlaşılamamıştır. Böyle durumlarda önergenin hangi şekilde kabul edileceğine bazen önerge sahibi, bazen de Meclis karar vermiştir.

Netice olarak II. Meşrutiyet Dönemi'nin neredeyse tamamında soru önergelerinin kesin olarak belirlenmiş kurallardan ziyade, zamanla oluşan teamüllere göre işlediğini söylemek mümkündür.

II. Meşrutiyet Dönemi’nde 94 soru önergesi verilmiştir. I. Yasama Dönemi’nde 48 soru önergesi, II. Yasama Dönemi'nde 4 soru önergesi, III. ve IV. Yasama Dönemlerinde ise 21 soru önergesi verilmiştir. II. Meşrutiyet dönemindeki ilk soru önergesi 26 Ocak 1909'da verilmiştir. Meclis'in 17 Aralık 1908 tarihinde açıldığı düşünüldüğünde, ilk soru önergesinin yaklaşık kırk gün sonra verildiği görülür. Hâlbuki ilk gensoru önergesi Meclis'in açılmasından on bir gün sonra verilmiştir.

Birinci Yasama Dönemi'nde (1908-1912) mebuslar ağırlıklı olarak, kendi seçim mahallerine ait sorular sormuştur. Bunlar arasında deprem, halkın durumu, veba, kolera gibi hastalıklar, idarecilerin tayin ve yolsuzlukları gibi konular sayılabilir. Bunun yanında birçok defa Balkanlardaki karışık durum ve Arnavutluk'ta başlayan isyan hareketi de soru olarak sorulmuştur. Üçüncü Yasama Dönemi'nde (19141918) ise tabiî olarak askerî konulara ait sorular sorulmuştur. Dördüncü Yasama Dönemi’nde (1920) ise 
işgal güçlerinin mezalimleri, sansür, idare-i örfiye ve Divan-1 Harp'e ait konuların sorulduğu dikkati çekmektedir.

II. Meşrutiyet Dönemi'nde verilmiş olan 94 soru önergesinden 84'ü kabul edilmiş ve 47'si de cevaplandırılmıştır. Bunun yanında soru önergelerinin 6'sı reddedilmiş, 2'sinin görüşülmesi ertelenmiş, 1'i geri alınmış ve 5'i de gensoruya dönüştürülmüştür. Verilen soru önergelerinden sadece iki tanesi yazılı soru, diğerleri sözlü sorudur.

II. Meşrutiyet Dönemi'nde en çok soru önergesi toplam 30 adet olmak üzere, Dâhiliye Nazırlarının cevaplandırması için verilmiştir. Hükûmetin cevaplandırması istemiyle 23, Hariciye Nazırlarının cevaplandırması istemiyle 11, Sadrazamların cevaplandırması istemiyle 8, Harbiye Nazırlarının cevaplandırması istemiyle 6, Ticaret ve Nafia, Maliye, Orman ve Maadin ve Ziraat Nazırlarının cevaplandırması istemiyle 4'er, Adliye Nazırlarının cevaplandırması istemiyle 3, Maarif ile Ticaret ve Ziraat Nazırlarının cevaplandırması istemiyle ise 2'şer soru önergesi verilmiştir. 


\section{Sonuç}

Kanun-1 Esasi ve Meclis-i Mebusan Dâhilî Nizamnamesindeki hukukî eksikler ve mebusların parlamenter denetimin hukukî alt yapısından mahrum olmalarından dolayı, I. Meşrutiyet Dönemi'nde sistemli ve istikrarlı bir parlamenter denetimden söz edilemez. Bu nedenle I. Meşrutiyet’teki parlamenter denetim daha çok mebusların yetenekleri, cesaretleri ve o ana kadar kazandıkları bilgi birikimiyle sınırlı kalmıştır.

Parlamenter denetim açısından, II. Meşrutiyet Dönemi daha sistemli ve istikrarlıdır. Zira 1909 yılında Kanun-1 Esasi'de yapılan değişikliklerle, parlamenter sistem oldukça demokratik bir yapıya kavuşturulmuştur. Yasamanın önündeki birçok engel kaldırılmış ve yürütme karşısında yasama kuvvetlendirilmiştir. Parlamenter denetim açısından en önemli değişiklik ise hükûmetin meclise karşı sorumlu hale getirilmiş olmasıydı. Nazırlar, hükûmetin genel siyasetinden müştereken ve kendi nezaretlerindeki işlerden de şahsen sorumlu olacaklardı. Bir nazır hakkında mecliste güvensizlik oyu verilirse nazır görevinden düşecekti. Sadrazam hakkında güvensizlik oyu verilirse hükûmet düşecekti. I. Meşrutiyet deneyiminden yararlanan ve 1909 yılındaki anayasal değişikliklerden destek alan mebuslar, II. Meşrutiyet Dönemi’nde dikkate değer bir parlamenter denetim gerçekleştirmişlerdir.

Genelde meclislerde en çok kullanılan denetim vasıtası, kullanım kolaylığından dolayı soru önergesidir. Ancak II. Meşrutiyet Dönemi Meclislerinde durum böyle olmamıştır. II. Meşrutiyet Dönemi’nde 166 gensoru önergesine karşıl1k, 94 soru önergesi verilmiştir. Bu durumun en önemli sebebi ise Kanun-1 Esasi'de ve Mebusan İçtüzügünde soru ile ilgili bir kuralın olmamasıdır. Mebuslar hukukî kayıttan yoksun olduğu için ilk başlarda soru önergesi ile sorulabilecek birçok konuyu, gensoru önergeleriyle sormuşlardır. Ayrıca hukukî kayıttan yoksun olduğu için soru önergeleri, mecliste aynı gensoru gibi işlem görmüştür. Soru önergelerinin kabul edilmesi için meclis oylamasına gerek olmadığ 1 halde, II. Meşrutiyet'in ilk günlerinde soru önergeleri de aynı gensoru gibi Meclis tarafindan kabul edilmiştir. Yine soru önergelerinin cevaplanmasından sonra, cevabın yeterliliğinin oylanmasına gerek olmadığı halde, soruya muhatap olan kişinin açıklamalarının yeterliliği oya sunulmuştur. Normal şartlarda şeklî eksikler dışında, soru önergesi reddedilememesine rağmen II. Meşrutiyet Dönemi'nde 6 adet soru önergesi çoğunluğun kararıyla reddedilmiştir.

Sonuç olarak, 1908'de Meclis'in açıldığı ilk zamanlarda hukukî kayıttan yoksun olduğu için mebuslar soru yerine çoğunlukla gensoruyu kullanmışlardır. Ancak zamanla gensoru ile soru arasındaki fark ortaya çıktıkça teferruata ait konular için soruyu, daha önemli konular için ise gensoruyu kullanmaya başlamışlardır. Diğer yandan mevzuatta olmadığı için II. Meşrutiyet Dönemi'nde soru önergeleri kesin olarak belirlenmiş kurallardan ziyade, zamanla oluşan teamüllere göre işlemiştir. 


\section{Kaynakça}

Aksoy, Batıkan. "Bakanlar Kurulunun TBMM tarafından Denetim Yollarından Biri Olarak Soru Önergesi”, Yüksek Lisans Tezi, Gazi Üniversitesi, 2003.

Armağan, Servet. Memleketimizde İçtüzükler, İstanbul 1972.

Balta, Tahsin Bekir. Türkiye'de Yürütme Kudreti, Ankara 1960.

Başgil, Ali Fuat. Esas Teşkilât Hukuku, İstanbul 1960.

Bülbül, Mahmut, "Parlamenter Denetim Yolları”, Kadınlara Yönelik Çalışmalar Yürüten Sivil Toplum Kuruluşlarının Yasama Sürecine Katılımlarının Güçlendirilmesi Semineri, 5-6 Kasım 2009, Ankara 2009, Yasama Derneği, s. 1-11.

Gazel, Ahmet Ali. Osmanlı Meclis-i Mebusan'1nda Parlamenter Denetim (1908-1920), Konya 2017.

Gençkaya, Ömer Faruk. "Parlamenter Bilgi Edinme ve Denetim Aracı Olarak Soru", Parlamenter Denetim Sempozyumu 07/05/2012, Ankara, s. 66-73.

Google. https://www.mevzuat.gov.tr/MevzuatMetin/1.5.2709.pdf (18.08.2021)

Güneş, Turan. Parlamenter Rejimin Bugünkü Manası ve İşleyişi, İstanbul 1956.

İba, Şeref. Parlamenter Denetim Yolları, Etkinliği ve Susurluk Örneği, Ankara 1997.

İba, Şeref. Türkiye'de Meclis Başkanlığı ve Başkanlık Divanı, Ankara 2001.

İslâm, Nadir Latif. Türkiye'de Gensoru ve Meclis Tahkikatı, Ankara 1966.

Kili, Suna; Gözübüyük. A. Şeref, Türk Anayasa Metinleri, İstanbul 2000.

Meclis-i Mebusan Zabıt Ceridesi, Dönem 1, 2, 3, 4.

Meclis-i Mebusan Nizamnâme-i Dahilisi, İstanbul 1331.

Özbudun, Ergun. Parlâmanter Rejimde Parlamentonun Hükûmeti Murakebe Vasitaları, Ankara 1962.

Resmî Gazete, 13 Nisan 1973, Say1: 14506; 21 Kasım 1981, Sayı: 17521; 24 Mayıs 1996, Say1: 22645.

Savc1, Bahri. "Parlamenter Rejimli Hükûmetin Unsurları", Siyasal Bilgiler Okulu Dergisi, IV, Sayı: 1, 2 ve 3, 4, Ankara 1949, s. 24-67.

Teziç, Erdoğan. Türk Parlamento Hukukunun Kaynakları ve İlgili Anayasa Mahkemesi Kararları, İstanbul 1980.

Yazıc1, Sibel. "Osmanlı Meclis-i Mebusanı ve Faaliyetleri (1914-1918)”, Doktora Tezi, Afyon Kocatepe Üniversitesi, 2018. 